\title{
Lecythis pisonis Cambess (sapucaia): seed morphometric traits and germinative response
}

\author{
Victor José Mendes Cardoso * \\ Evandro Afonso Nakao \\ Universidade Estadual Paulista Júlio de Mesquita Filho, Departamento de Botânica \\ Avenida 24A, 1515, CEP 13506-900, Rio Claro $\square$ SP, Brasil \\ * Autor para correspondência \\ victorjc@rc.unesp.br
}

Submetido em 24/03/2013

Aceito para publicação em 22/10/2013

\section{Resumo}

Lecythis pisonis Cambess (sapucaia): características morfométricas da semente e resposta germinativa. Este estudo objetivou testar possível correlação entre germinação e as variáveis massa e densidade de sementes de Lecythis pisonis (sapucaia), bem como levantar questões que possam contribuir para o conhecimento da germinação dessa espécie. Para tanto, acompanhou-se o processo de embebição e germinação de sementes intactas e escarificadas de L. pisonis em condições controladas $\left(26^{\circ} \mathrm{C}\right.$, com irradiância média de $34.6 \mu \mathrm{mol}^{-} \mathrm{m}^{-}$ ${ }^{2} \cdot \mathrm{s}^{-1} \mathrm{e}$ no escuro). Em outro ensaio, sementes de sapucaia foram individualmente caracterizadas quanto à massa e densidade, sendo, então, semeadas em caixas plásticas preenchidas com solo e mantidas em ambiente natural (irradiância média de $\pm 12.5 \mu \mathrm{mol} \cdot \mathrm{m}^{-2} \cdot \mathrm{s}^{-1}$ às $12: 00$ ), com temperaturas variando de 15 a $32^{\circ} \mathrm{C}$. A germinação (emergência da parte aérea) de cada semente foi acompanhada no período de setembro de 2009 a janeiro de 2010. Os resultados sugerem que a testa não representa um fator restritivo para a embebição e germinação de sapucaia. A germinação aumentou proporcionalmente com o aumento da densidade da semente. Com base nos resultados, recomenda-se o uso de sementes com densidades $>0,9 \mathrm{~g} \cdot \mathrm{mL}^{-1}$, para garantir uma porcentagem elevada de plântulas.

Palavras-chave: Densidade da semente; Massa da semente; Plântula; Sapucaia

\section{Abstract}

This study aimed to test a possible correlation between germination and the variables weight and density of seeds of Lecythis pisonis (sapucaia), as well as raise issues which may contribute to know germination in this species. For this, we followed up the soaking and germination process of intact and scarified seeds of L. pisonis under controlled conditions $\left(26^{\circ} \mathrm{C}\right.$, with average irradiance of $34.6 \mu \mathrm{mol} \cdot \mathrm{m}^{-2} \cdot \mathrm{s}^{-1}$ and in the dark). In another trial, seeds of sapucaia were individually characterized with regard to weight and density, and, then, sown in plastic boxes filled with soil and kept in a natural environment (average irradiance $\pm 12.5 \mu \mathrm{mol} . \mathrm{m}^{-2} . \mathrm{s}^{-1}$ at 12:00 p.m.), with temperatures ranging from 15 to $32^{\circ} \mathrm{C}$. The germination (shoot emergence) of each seed was followed up within the period from September 2009 to January 2010. The results suggest that the coat does not represent a restrictive factor for soaking and germination of sapucaia. Germination increased proportionally to the increase in seed density. Based on these results, we recommend the use of seeds with densities $>0.9 \mathrm{~g} . \mathrm{mL}^{-1}$, in order to ensure a high percentage of seedlings.

Key words: Sapucaia; Seed density; Seedling; Seed weight 


\section{Introduction}

Tree regeneration in lowland tropical forests is mainly done by seeds (RAICH; KHOON, 1990), thus, studies on germination may help us understand the ecophysiology and the distribution of species within a community, and they also provide important clues concerning seed technology and species management. Lecythis pisonis Cambess (Lecythidaceae), commonly named $\square$ sapucaia $\square$ in Brazil, is a tall (up to $35 \mathrm{~m}$ ) and wide $(1.5 \mathrm{~m})$ tree when growing in isolation. The species is either classified as early secondary (CARVALHO, 2006) or shade-tolerant climax and it occurs naturally in the Atlantic Forest and in the Amazon, being endemic to Brazil (CARVALHO et al., 2006).

The seed of sapucaia (1.7-2.6 cm wide and 3.6-4.3 $\mathrm{cm}$ long) is angular, grooved, and it has a white pulpy aril at the end opposite to the micropyle (PAGOTTO, 1982; CARVALHO, 2006; BRAGA et al., 2007). According to Floriano (2004), the aril must be removed to overcome seed dormancy, while Carvalho (2006) reports that seeds of sapucaia require no pre-treatment for germination. Regarding longevity, the seeds are classified as orthodox (desiccation-tolerant) and they can be stored at $5^{\circ} \mathrm{C}$ or $-18^{\circ} \mathrm{C}$ without viability loss (CARVALHO, 2006; CARVALHO et al., 2006). The emergence of seedlings of sapucaia has been reported to take place between 30 and 90 days after sowing (CARVALHO, 2006).

According to Braga et al. (2007), although seeds of Lecythis pisonis are relatively uniform in length, the sample of seeds analysed by the autors was heterogeneous in terms of width, thickness, and weight. Thus, it is possible to see that seeds of $L$. pisonis may vary in terms of morphometric traits even within the same sample, and this variations may be related to changes in the seed physiological traits, such as germinability and germination rate (ANDERSSON, 1996; SCARPA; VALIO, 2008). This study aimed to test a possible relation between seed morphometric traits and germination of seeds of sapucaia, thus contributing to projects focused on species propagation, as well as raising issues on the germination process.

\section{Materials and Methods}

Fruits were collected from a population of $6 \mathrm{~L}$. pisonis Cambess individuals growing in Rio Claro, São Paulo, Brazil $\left(22^{\circ} 23 \square 6.08 \square\right.$ S and $47^{\circ} 32 \square 47.75 \square$ W) in September and October 2009. The fruits were transported to the laboratory and left on a bench under two $40 \mathrm{~W}$ fluorescent tubes at room temperature (22$28^{\circ} \mathrm{C}$ ), and the seeds were, then, removed from these fruits whose operculum spontaneously detached up to 10 days after harvest. Fruits containing seeds whose opercula had already dropped were also collected. After detachment of the operculum, the seeds were manually extracted and the aril was removed, then, the seeds were placed in plastic trays at room temperature, where they remained for up to 8 days before being used in trials.

In the first trial (trial I), a sample of 72 seeds was randomly removed from the batch and it was divided into 2 groups with 36 seeds each. To test the possible influence of the seed coat, seeds from a group were mechanically scarified in a small area (about $0.5 \mathrm{~cm}^{2}$ ) on the mid-section of the seed using an emery, while the other group of seeds were left intact. Each seed was, then, weighed on a precise weighing scale of two decimal points, wrapped in filter paper kept saturated with distilled water, and put into six $12 \mathrm{~cm} \mathrm{x} 12 \mathrm{~cm} \mathrm{x}$ $3.5 \mathrm{~cm}$ germination boxes (Gerbox), with 6 seeds per Gerbox. The boxes were placed at $26^{\circ} \mathrm{C}$, either under fluorescent tubes $\left(34.6 \mu \mathrm{mol} . \mathrm{m}^{-2} . \mathrm{s}^{-1}\right)$ or in the dark in growth cabinets. Under dark conditions, black boxes were used. The effect of white light was analyzed with regard to possible photoblastic behaviour of seeds, since no information on that issue was found in the scientific literature. Each seed was daily removed from the Gerbox, inspected for radicle protrusion, weighed, and returned to the same box. Water uptake by seeds (I) was determined by means of the formula: $\mathrm{I}=\left[\left(\mathrm{m}_{\mathrm{tn}}-\mathrm{m}_{\mathrm{t} 0}\right) /\right.$ $\left.\mathrm{m}_{\mathrm{t} 0}\right] .100$, where $\mathrm{m}_{\mathrm{tn}}=$ seed fresh weight at time $\mathrm{n}$ and $\mathrm{m}_{\mathrm{t} 0}$ $=$ seed fresh weight at time zero. As we evaluated the variance normality and homogeneity, the mean I values and the respective standard deviations and interval confidence $(\alpha=0.05)$ were calculated.

Other trial (trial II) was carried out to evaluate the relation between the emergence of seedlings and seed 
density; 124 seeds were individually weighed and the volume $(\mathrm{V})$ of each seed was determined by suspending the seed on 92.8 GL ethanol in a beaker placed on the pan of a semi-analytical scale. The volume of the immersed seed consists in the weight increase divided by the fluid density: $\mathrm{V}=\Delta_{\mathrm{w}} / \rho$, where $\Delta_{\mathrm{w}}$ is the change in weight and $\rho$ is the density measured (HUGHES, 2005). Seed density (D) was calculated by means of the formula: $\mathrm{D}=\mathrm{mV}^{-1}$, where $\mathrm{m}$ refers to seed fresh weight. Then, seeds were sown in six $58 \mathrm{~cm}$ x $38 \mathrm{~cm}$ x $30 \mathrm{~cm}$ plastic trays filled with a $20 \mathrm{~cm}$ deep layer of sandy soil enriched with plant litter (78\% sand and 30\% organic matter). The seeds were buried in the substrate with the longitudinal axis parallel to the surface and the upper side of the tegument, facing the substrate surface. Trays were kept under natural shading (average irradiance $\pm 12.5 \mu \mathrm{mol} . \mathrm{m}^{-2} . \mathrm{s}^{-1}$ at noon and $\pm 4.8 \mu \mathrm{mol} . \mathrm{m}^{-2} . \mathrm{s}^{-1}$ in early morning and late afternoon) with temperatures ranging from 15 to $32^{\circ} \mathrm{C}$. After sowing, the substrate - kept moist throughout the experiment - was covered with a $3 \mathrm{~cm}$ deep layer of dry leaves of sapucaia (3 trays) or other species (3 trays), in order to simulate a "natural" condition and evaluate a possible influence of the leaf cover, taking into account the fall of leaves at the seed dispersion time. However, considering that no difference in the emergence of seedlings was observed between the 2 types of cover, data from the 6 trays were pooled. The germination (shoot emergence) of each seed was registered from September 2009 to January 2010. The pooled data on seed density and fresh weight were grouped into 8 classes, the frequency polygon was drawn through the class marks and the number of germinated seeds within each interval was recorded.

\section{Results}

The soaking of seeds kept on filter paper rolls moistened with distilled water was more marked within the first $24 \mathrm{~h}$ and it decreased in later measurements (Figure 1). Taking into account that there was no difference between the dark and the white light treatments (confidence interval $\alpha=0.05$ ), the seeds soaked in both treatments were regarded as a single group. A slight increase in water uptake was observed in scarified seeds, when compared to intact seeds, within the first $150 \mathrm{~h}$ of the trial, although the difference

FIGURE 1: Time course of water uptake by Lecythis pisonis seeds in filter paper rolls saturated with distilled water. Soaking of scarified seeds (squares) and intact seeds (triangles) under white light (open symbols) and darkness (dark symbols) is displayed. Bars $=$ confidence intervals $(\alpha=0.05)$.

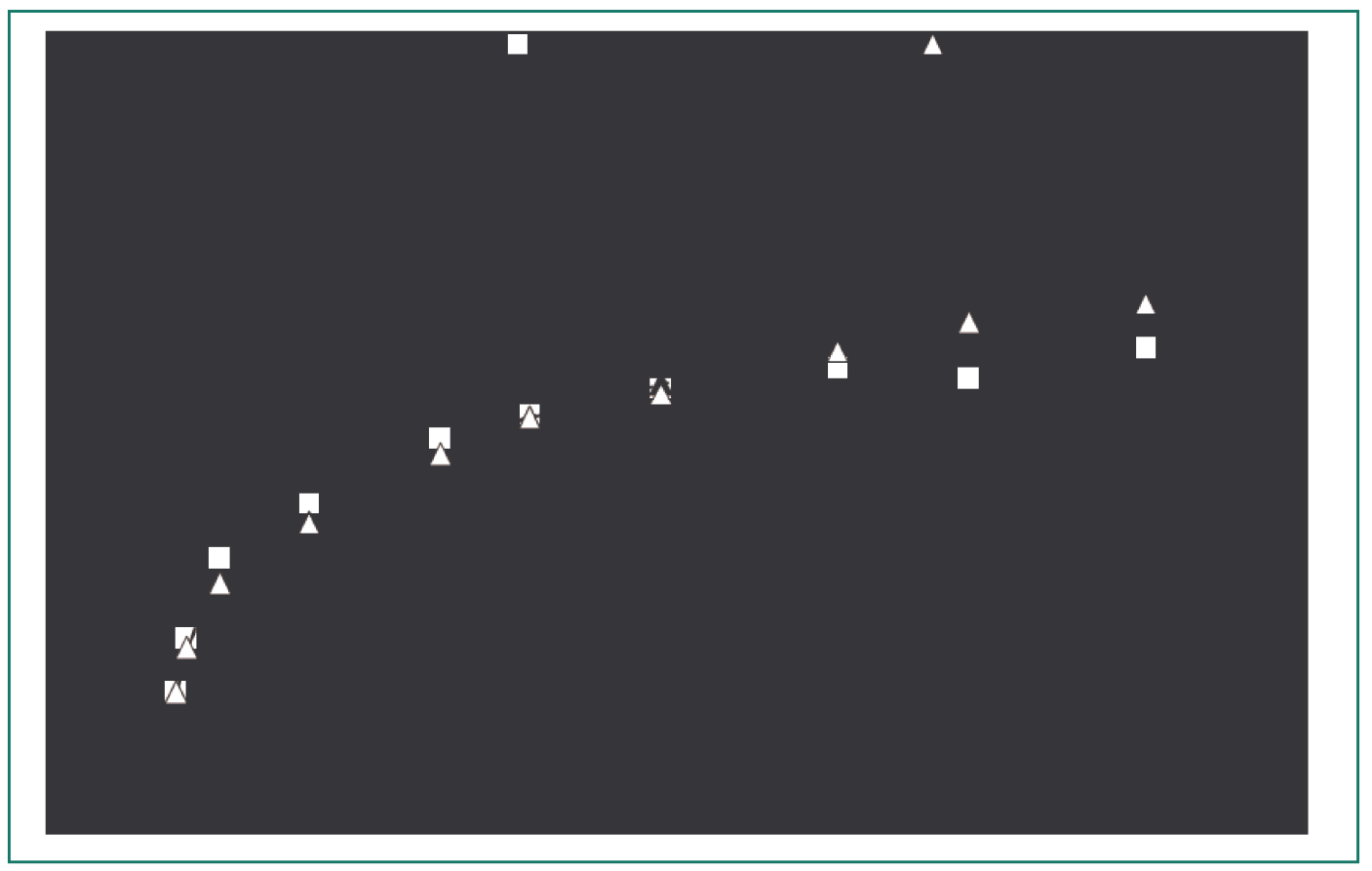

\section{Demo Version, http://www.verydoc.com and http://www.verypdif.com}


between treatments disappeared after that period. It was also observed that the soaking curve of scarified seeds stabilised after $264 \mathrm{~h}$ (11 days), while the curve of intact seeds showed a steady, albeit slow, increase throughout the trial (Figure 1). Under the experimental conditions adopted (full water availability and temperature $\cong 26^{\circ} \mathrm{C}$ ), germination (radicle protrusion) occurred between 15 and 31 days (average of $19.5 \pm 1.5$ days) after sowing. Within the scarified batch, only 1 seed germinated after 25 days of soaking. The seeds used in the experiments weighed $4.8 \pm 0.2 \mathrm{~g}$ per seed (fresh weight, FW). The FW of newly collected seeds decreased from $6.2 \pm 0.3 \mathrm{~g}$ to $4.5 \pm 0.2 \mathrm{~g}$ after the seeds were left for 8 days on the lab bench at room temperature $\left(22-28^{\circ} \mathrm{C}\right)$ and relative air humidity $\cong 75 \%$, thus corresponding to a moisture loss around $27 \%$.

In trial II, we observed that the seed density showed a low $\left(\mathrm{R}^{2}=0.3\right)$ correlation with $\mathrm{FW}$ and it was not correlated $\left(\mathrm{R}^{2}=0.006\right)$ with $\mathrm{V}$ (data not shown). The sprouting of seeds with densities ranging from $0.3 \mathrm{gmL}^{-1}$ to $0.70 \mathrm{gmL}^{-1}$ was null, while in seeds with densities > 0.70 g. $\mathrm{mL}^{-1}$ the proportion of germinated seeds related to $\mathrm{N}$ (number of seeds per class) increased according to seed density (Figure 2a). Considering the seed sample size $(n=124)$, the distribution of densities differed from normal and showed a bi-modal pattern, with a lower number of seeds in the density classes ranging from

FIGURE 2: Frequency distribution of seed density (A) and fresh weight (B) of Lecythis pisonis. $\mathrm{N}=124$. Open bars $=$ number of sampled seeds; shaded bars $=$ number of germinated seeds.

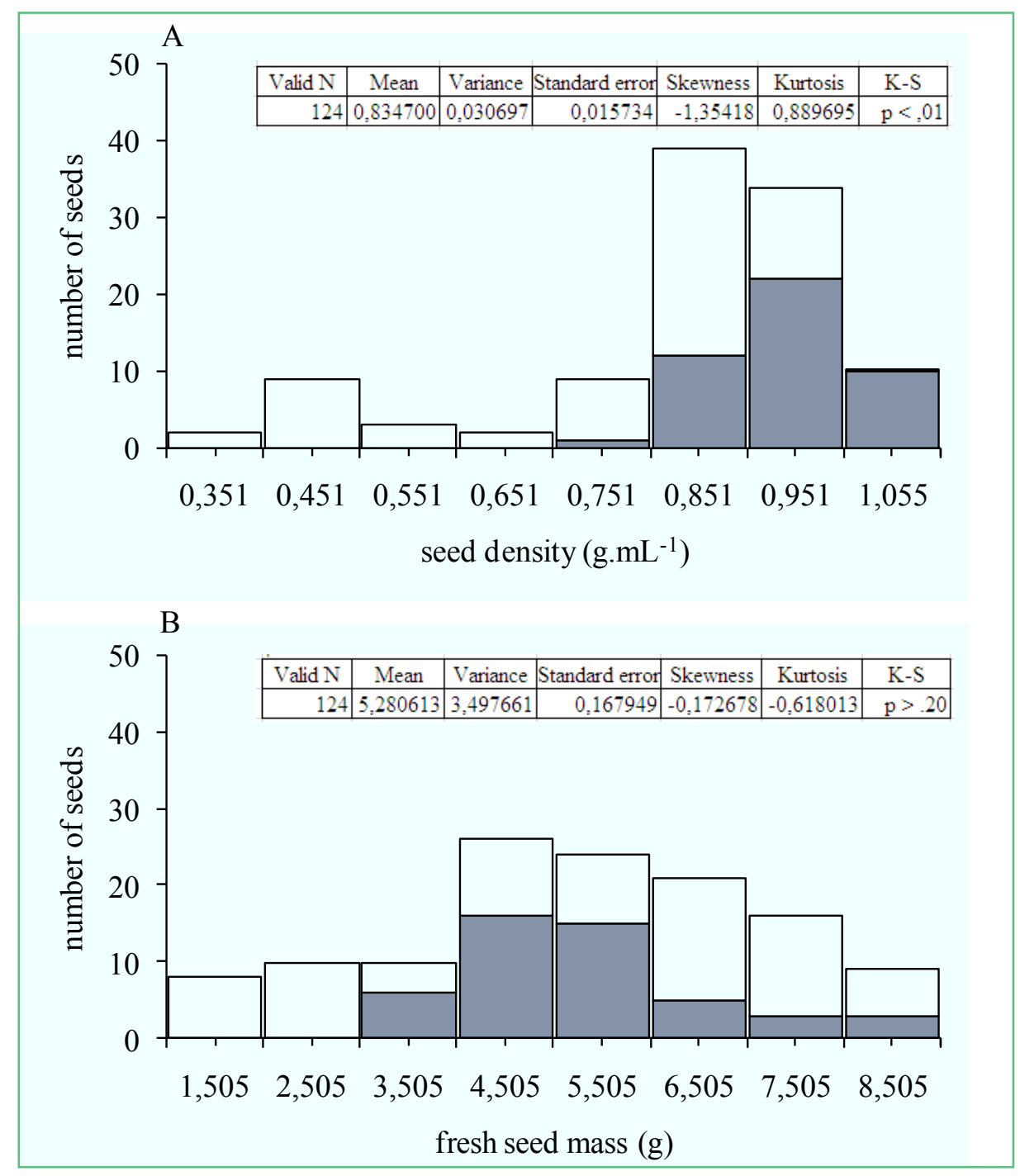


0.301 to 0.700 g.mL $\mathrm{mL}^{-1}$ and a large amount of seeds with densities ranging from 0.701 to 1.100 g. $\mathrm{mL}^{-1}$ (Figure 2a). The relation between shoot emergence and fresh weight (FW) was not clear, with seeds from the intermediate FW classes (3.01-6.00 g) sprouting proportionally more than those from the heavier class (above $6.01 \mathrm{~g}$ ) (Figure $2 b$ ). The frequency distribution of FW did not differ from normal (K-S, p > 0.2), and it exhibits a left-skewed and platicurtic pattern.

In trial II, where seeds were sown directly in containers with substrate, the average time to shoot emergence was $55 \pm 3.3$ days. A determination coefficient $\left(\mathrm{R}^{2}\right)$ of 0.004 was found between germination proportion and fresh weight, while a $\mathrm{R}^{2}=0.959$ was observed for the relation between germination and seed density from $0.601 \mathrm{~g} \cdot \mathrm{mL}^{-1}$. Non-germinated seeds at the end of trials (123 days) were visually inspected and all of them showed deterioration signs.

\section{Discussion}

Seeds of Lecythis pisonis were soaked relatively fast in the first $24 \mathrm{~h}$, in accordance to Pagotto (1982), who reported that hydration of the seeds of sapucaia stabilises at around $3 \%$ after this time, probably due to the extremely hard $\square$ seed coat. In this article, we report that the soaking of intact seeds steadily increased throughout the trial period (nearly 22 days) and it attained values $>40 \%$ before radicle protrusion. Scarification caused a slight increase in the soaking time course, but it had no effect on the final seed hydration percentage, showing that, contrary to Pagotto (1982), but in accordance to Carvalho (2006), the seed coat was not the main limiting factor for soaking the seeds of sapucaia, and no pretreatment for germination is required for the species. However, seeds of $L$. pisonis from different batches or harvests may differ to one another in terms of seed coat resistance to water uptake, as reported for some species (LACERDA et al., 2004).

In this study, we found a fresh weight value of 5.28 $\mathrm{g} / \mathrm{seed}^{-1}$, while Pagotto (1982) and Braga et al. (2007) used seeds which weighed $4.71 \mathrm{~g}$ and $8.65 \mathrm{~g}$, respectively. The FW of freshly collected seeds of sapucaia decreased nearly $27 \%$ after being left under room conditions, thus, both the time between seed collection and measurement and the storage conditions may influence on the FW values. According to Carvalho et al. (2006), the decrease of seed moisture from $20.8 \%$ to $6.2 \%$ did not affect the germination of $L$. pisonis seeds, which was classified as orthodox (desiccation-tolerant). It has been reported that the germination (shoot emergence) capacity of seeds of sapucaia ranges from $51 \%$ to $68 \%$ (CARVALHO, 2006), and it is only moderate (LORENZI, 1992).

Around $72 \%$ of the seeds used in this study showed FW values (weight per seed) ranging from 3.37 to 7.36 g, while Pagotto (1982) and Braga et al. (2007) reported the highest frequency of seeds in the ranges from 3.1 to $5.0 \mathrm{~g}$ and from 7.0 to $9.9 \mathrm{~g}$, respectively. The volume of individual seeds of sapucaia was correlated with FW, mainly in seeds where germinability was either medium or high, and showed relatively high densities (weight volume $^{-1}$ ). The germination (shoot emergence) of seeds of sapucaia with density $\geq 0.901 \mathrm{~g}$. $\mathrm{L}^{-1}$ was $>60 \%$ and it was null at density classes $<0.701$ g.L $\mathrm{L}^{-1}$. The relation between seed density and germination capacity is known, and the results found here are similar, for example, to those found by Krieg and Bartee (1975), who reported that the germination of seeds of Gossypium hirsutum L. is positively related to seed density. These authors also reported that the cotton seed quality depends more on seed density than on seed size or weight, and that density is closely related to the embryo maturity status, being more independent of genotype than other seed trait.

Therefore, for obtaining a relatively high percentage of seedlings of sapucaia, we may recommend to sow seeds whose density is $>0.901 \mathrm{gmL}^{-1}$, and their germination can reach values $>60 \%$. Seeds of sapucaia with $\mathrm{FW}<3.01 \mathrm{~g}$ did not germinate, whilst seeds with FW ranging from $3.01 \mathrm{~g}$ to $6.0 \mathrm{~g}$ produced the largest number of seedlings. However, the relation between shoot emergence and FW was not as evident as it was with regard to the relation between emergence and seed density. Thus, the FW variable, taken in isolation, is not a good indicator of physiological seed quality in L. pisonis, although fresh weight is a variable easier to measure than density. Taking into account the dependence on variation of the seed morphometric traits, the results obtained here need to be corroborated by other regional evaluations in 
order to draw strong conclusions, with potential to be applied to a wider range of seed morphotypes.

\section{References}

ANDERSSON, S. Seed size as a determinant of germination rate in Crepis tectorum (Asteraceae): evidence from a seed burial experiment. Canadian Journal of Botany, Ottawa, v. 74, n. 4, p. 568-572, 1996.

BRAGA, L. F.; SOUSA, M. F.; GILBERTI, S.; CARVALHO, M. A. C. Caracterização morfométrica de sementes de castanha de sapucaia (Lecythis pisonis Cambess $\square$ Lecythidaceae). Revista de Ciências Agro-Ambientais, Cáceres, v. 5, n. 1, p. 111-116, 2007.

CARVALHO, L. R.; SILVA, E. A. A.; DAVIDE, A. C. Classificação de sementes florestais quanto ao armazenamento. Revista Brasileira de Sementes, Londrina, v. 28, n. 2, p. 15-25, 2006.

CARVALHO, P. E. R. Espécies arbóreas brasileiras. Brasília: Embrapa, 2006. 627 p.

FLORIANO, E. P. Germinação e dormência de sementes florestais. Santa Rosa: ANORGS $\square$ Série Cadernos Didáticos, 2004. 19 p.
HUGHES, S. W. Archimedes revisited: a faster, better, cheaper method of accurately measuring the volume of small objects. Physics Education, Queensland, v. 40, n. 5, p. 468-474, 2005.

KRIEG, D. R.; BARTEE, S. N. Cottonseed density: associated germination and seedling emergence properties. Agronomy Journal, Madison, v. 67, n. 3, p. 343-347, 1975.

LACERDA, D. R.; LEMOS FILHO, J. P.; GOULART, M. F.; RIBEIRO, R. A.; LOVAT, M. B. Seed-dormancy variation in natural populations of two tropical leguminous tree species: Senna multijuga (Caesalpinoideae) and Plathymenia reticulata (Mimosoideae). Seed Science Research, Wageningen, v. 14, n. 2 p. $127-135,2004$

LORENZI, H. Árvores brasileiras. São Paulo: Ed. Plantarum, $1992.368 \mathrm{p}$

PAGOTTO, T. C. S. Estudos ecofisiológicos de Lecythis pisonis Cambess. 1982. 227 f. Tese (Doutorado em Ciências Biológicas) $\square$ Universidade Estadual Paulista $\square$ úlio de Mesquita Filho $\square$, Rio Claro. 1982

RAICH, J. W.; KHOON, G. Effect of canopy openings on tree seed germination in a Malayan dipterocarp forest. Journal of Tropical Ecology, Winchelsea, v. 6, n. 2, p. 203-217, 1990.

SCARPA, F. M.; VALIO, I. F. M. Relationship between seed size and litter effects on early seedling establishment of 15 tropical tree species. Journal of Tropical Ecology, Winchelsea, v. 24, n. 5, p. 569-573, 2008. 